\section{Public Health Review - International \\ Journal of Public Health Research}

MEDRESEARCH

\title{
Awareness and practice of road safety measures among college going students in Guntur City
}

\author{
Dulipala P. ${ }^{1 *}$, Gujjarlapudi C. ${ }^{2}$ \\ DOI: https://doi.org/10.17511/ijphr.2016.i2.02 \\ 1* Phanindra Dulipala, Assistant professor, Department of Community Medicine, Katuri Medical College, Guntur, Andhra Pradesh, India. \\ 2 Chaitanya Gujjarlapudi, Associate professor, Department of Community Medicine, Katuri Medical College, Guntur, Andhra Pradesh, India.
}

\begin{abstract}
Background and Aim: In most regions of the world the global epidemic of traffic injuries is still increasing. It has been estimated that unless immediate action is taken, road deaths will rise to the fifth leading cause of deaths by 2030. Road Traffic Accidents (RTAs) are the leading cause of death among individuals aged 15 to 29 and second leading cause of mortality among 20-24 years of age. Simple measures such as awareness and practice of road safety measures can effectively reduce the impact of RTAs on the people's lives. The present study was aimed to assess the awareness levels of road safety measures among college students in Guntur city. Materials and Methods: The present cross sectional study was done among 450 college students. A pre-designed and pre-tested questionnaire for evaluation of the Knowledge, Attitude and Practices of two-wheeler driving was used. Results: History of using their own vehicles was given by $73.33 \%$ of the participants. Only $14.66 \%$ have ever attended awareness training program. Only $46 \%$ of the participants wear helmet while driving. Conclusion: The level of knowledge regarding road safety measures was satisfactory but interpretation of traffic signs was poor. Strict enforcement of laws and periodic organization of traffic awareness campaigns are essential for checking out risky practices in driving.
\end{abstract}

Keywords: Awareness, College students, Road Safety Measures

Corresponding Author

Phanindra Dulipala, Assistant professor, Department of Community Medicine, Katuri Medical College, Guntur, Andhra Pradesh, India. Email: drpdulipala@gmail.com
How to Cite this Article

Dulipala P, Gujjarlapudi C. Awareness and practice of road safety measures among college going students in Guntur City. Public Health Rev Int J Public Health Res. 2016;3(2):54-58.

Available From

https://publichealth.medresearch.in/index.php/ijphr/ article/view/31
To Browse

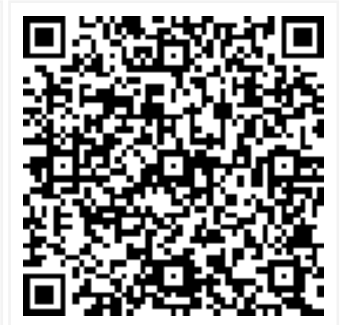

Manuscript Received 2016-03-02

Conflict of Interest No

Review Round 1
2016-03-12
Funding
Nil

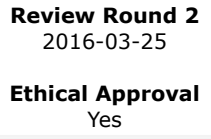

Review Round 3

Plagiarism X-checker $6 \%$
Accepted 2016-04-06

Note

(C) 2016 by Phanindra Dulipala, Chaitanya Gujjarlapudi and Published by Siddharth Health Research and Social Welfare Society. This is an Open Access article licensed under a Creative Commons Attribution 4.0 International License https://creativecommons.org/licenses/by/4.0/ unported [CC BY 4.0]. 


\section{Introduction}

In most regions of the world the global epidemic of traffic injuries is still increasing. It has been estimated that unless immediate action is taken, road deaths will rise to the fifth leading cause of deaths by 2030 . It may result in an estimated 2.4 million fatalities per year [1].

In recent years, some important studies on the subject of road accidents and fatalities carried out by World Health Organization (WHO) have highlighted the growing significance of road crashes as a cause of death particularly in developing countries [2].

Road Traffic Accidents (RTAs) are the leading cause of death among individuals aged 15 to 29 and second leading cause of mortality among 20-24 years of age [3]. In addition to fatalities, less severe injuries also occur leading to disabilities. In India an estimated 2 million people have a disability that results from a road traffic crash [4].

Road traffic injuries place a huge strain on health care services in terms of financial resources, bed occupancy and demand placed on health professionals. Studies in India show that road traffic injuries account for $20-50 \%$ of emergency room registrations, $10-30 \%$ of hospital admissions and $60-70 \%$ of brain injuries [5]. $91 \%$ of the world's fatalities on the roads occur in low income and middle income countries.

Approximately $62 \%$ of reported road traffic deaths occur in 10 countries - which in order of magnitude are India, China, The United States, The Russian Federation, Brazil, Iran, Mexico, Indonesia, South Africa, and Egypt [6]. A global survey shows that pedestrians, cyclists, and riders of motorized two wheelers and their passengers account for around $46 \%$ of global road traffic deaths [6].

It is estimated that without additional efforts and new initiatives, the total number of road traffic deaths worldwide and injuries is forecast to rise by some $65 \%$ between 2000 and 2020 [2]. In lowincome and middle-income countries the deaths are expected to increase by as much as $80 \%$ [2]. A number of these risks are elevated among young road users, including pedestrians, drivers and passengers of both cars and motorcycles.

Understanding the risks faced by the young road users is important in order to plan appropriate programmes to reduce road traffic deaths and
Injuries among this age group. Most of the interventions that reduce the risk of road traffic injuries among the general population will also reduce the occurrence among youth [7]. Simple measures such as awareness and practice of road safety measures can effectively reduce the impact of RTAs on the people's lives. The present study was aimed to assess the awareness levels of road safety measures among college students in Guntur city.

\section{Materials and Methods}

The present cross-sectional study was conducted in Guntur city, Andhra Pradesh. A total of 450 college students were randomly selected from places like cinema halls, shopping malls, colleges, etc. They all drive either their own or others' two-wheelers. They were aged between 17 to 29 years. The study period was from August to October, 2015. Oral consent was taken from the students participating in the study.

A pre-designed and pre-tested questionnaire for evaluation of the Knowledge, Attitude and Practices of two-wheeler driving was used. The complete data was compiled into MS EXCEL 2007 and analysis was done by SPSS version 21 .

\section{Results}

A total of 450 college students participated in the study. Among the participants, 238(52.8\%) were males and 212(47.2\%) were females, and $219(48.6 \%)$ were less than 20 years of age (Table I). History of using their own vehicles was given by $330(73.33 \%)$. Regarding awareness, only $66(14.66 \%)$ have ever attended awareness training program. As shown in Table II, majority of the participants were aware of road safety measures like wearing helmet, following of speed limit, not to use mobile phones while driving and checking the condition of the vehicle. But only 108(24.0\%) know that overtaking must be from right side only. The participants have very poor knowledge regarding interpretation of traffic signs (Table III).

Majority of the participants has appropriate attitude to the road safety measures (Table IV). Practice of road safety measures have been assessed among the participants (Table $\mathrm{V}$ ). Majority of the participants were having driving license, but about half of the participants were not wearing helmet during driving and $1 / 5$ th were involved in drunken driving in the past one year. 
Around half of the participants were attending the phone call while driving, drive bike with more than two persons and frequently exceed the speed limits.

Table I: Age and gender wise distribution of participants

\begin{tabular}{|l|l|}
\hline \multicolumn{1}{|c|}{ Variable } & \multicolumn{2}{c|}{ Number of students (\%) } \\
\hline AGE & $219(48.6)$ \\
\hline$\leq 20$ & $231(51.4)$ \\
\hline 20 & $238(52.8)$ \\
\hline GENDER & $212(47.2)$ \\
\hline Male &
\end{tabular}

Table II: Knowledge of students regarding road safety measures while using a motor vehicle

\begin{tabular}{|l|l|l|}
\hline $\begin{array}{r}\text { SI. } \\
\text { No. }\end{array}$ & \multicolumn{1}{|c|}{ Road safety measure } & Number of students (\%) \\
\hline 1 & Traffic awareness program attended & $66(14.66)$ \\
\hline 2 & Wearing helmet & $387(86.0)$ \\
\hline 3 & $\begin{array}{l}\text { Overtaking must be from right side } \\
\text { only }\end{array}$ & $108(24.0)$ \\
\hline 4 & Speed limit should be followed & $348(77.33)$ \\
\hline 5 & Do not use mobile phones while driving & $384(85.33)$ \\
\hline 6 & Check the condition of the vehicle & $289(64.22)$ \\
\hline
\end{tabular}

Table III: Awareness among study participants regarding road traffic signs

\begin{tabular}{|l|l|l|l|}
\hline SI. & Traffic sign & $\begin{array}{c}\text { Interpretation of } \\
\text { sign }\end{array}$ & \multicolumn{1}{|c|}{$\begin{array}{c}\text { Number of students } \\
(\%)\end{array}$} \\
\hline & & & \\
& & & \\
& & & \\
\hline
\end{tabular}

Table IV: Attitude of the participants towards road safety measures

\begin{tabular}{|l|l|l|}
\hline $\begin{array}{r}\text { SI. } \\
\text { No. }\end{array}$ & \multicolumn{1}{|c|}{ Variables } & \multicolumn{1}{|c|}{$\begin{array}{c}\text { Number of students } \\
(\%)\end{array}$} \\
\hline 1 & $\begin{array}{l}\text { Mobile phone should not be used while } \\
\text { driving }\end{array}$ & $369(82.00)$ \\
\hline 2 & $\begin{array}{l}\text { Regular maintenance of vehicle is } \\
\text { essential }\end{array}$ & $248(55.11)$ \\
\hline 3 & Listening to music while driving is alright & $33(7.33)$ \\
\hline 4 & Driving is safe after taking alcohol & $2(0.4)$ \\
\hline 5 & Exceeding the speed limit is safe & $3(0.6)$ \\
\hline
\end{tabular}

Table V: Practice of road safety measures among participants.

\begin{tabular}{|l|l|l|}
\hline SI. No & \multicolumn{1}{|c|}{ Variables } & Number of students (\%) \\
\hline 1 & Have driving license & $356(79.11)$ \\
\hline 2 & Wearing helmet while driving & $207(46.0)$ \\
\hline 3 & Driving under the influence of alcohol & $92(20.44)$ \\
\hline 4 & Attend phone call while driving & $236(52.44)$ \\
\hline 5 & Drive bike with more than two persons & $224(49.77)$ \\
\hline 6 & Exceeding speed limits while driving & $231(51.33)$ \\
\hline
\end{tabular}

\section{Discussion}

The present study was conducted to assess the knowledge, attitude and practice of road safety measures among college students. The male students were slightly higher than female students. In the present study, $73.33 \%$ of the participants used their own vehicles. Similar findings were observed in a study conducted by Al-Khaldi in Saudi Arabia where nearly $70 \%$ participants used their own vehicles [8].

Awareness of road safety measures among the participants was good. This may be due to the increase in campaigning through mass media. But only $108(24.0 \%)$ know that overtaking must be from right side only. This may be due less addressing of this issue in comparison to the other measures.

In the interpretation of traffic signs, the knowledge of the participants was not satisfactory. Similar finding was observed by Gharaibeh et al. in a study conducted in Saudi Arabia [9]. This is an issue of concern to be looked after as traffic signs are of high importance in reducing RTAs. Majority of the participants has healthy attitude to the road safety measures in similar to the findings observed by Lalitha et. al. in their study conducted in Visakhapatnam [10]. Regarding the practice of road safety measures, nearly $20 \%$ of the participants were not having a driving license. 
Only less than half were using helmets and $1 / 5$ th of them were involved in drunken driving during the past year. Our findings were similar to the observation in the study conducted by Swamy et al. in Chandigarh [11]. Such high risk taking behavior among the study participants is alarming. Alcohol and driving is a well-known notorious combination responsible for an increased morbidity and mortality associated with road traffic accidents.

Around half of the participants admitted to the use of mobile phones while driving, drive bike with more than two persons and agreed to having exceeded speed limits while driving. These findings are similar to studies conducted by Gharaibeh et al. in Saudi Arabia [9] and Kulkarni V, et al. in South India [12].

The behaviors concerning mobile usage and overspeeding while driving are highly dangerous to the driver and to the public. Hence, these behavior patterns need to be addressed through proper legislative and educative measures. Practices relating to road safety should be encouraged to reduce the morbidity and mortality related to road traffic accidents.

\section{Conclusion}

The level of knowledge regarding road safety measures was satisfactory but interpretation of traffic signs was poor. Efforts should be made in improving this issue through signboards, posters and mass media. Even though a positive attitude was observed, the practice of road safety measures was very poor. Strict enforcement of laws and periodic organization of traffic awareness campaigns are essential for checking out risky practices in driving and thereby can result in decreasing the burden of road traffic accidents.

\section{Reference}

01. World health statistics 2008. Geneva- World Health Organization. 2008. Available from: [Article] [Crossref]

02. Mittal N. Policies and programs for road safety in developing India. J Emerg Trauma Shock. 2008 Jan;1(1)42-9.

doi: $10.4103 / 0974-2700.41790$ [Crossref]

03. Global status report on road safety- time for action. Geneva- World Health Organization. 2009. Available from:

[Article] [Crossref]
04. Gururaj G. Road Traffic injury prevention in India. Bangalore, National Institute of Mental Health and Neuro sciences. 2006.

[Crossref]

05. Gururaj G. Road traffic deaths, injuries and disabilities in India- current scenario. Natl Med J India. 2008;21(1)14-20.

[Crossref]

06. The global burden of disease - 2004 update. Geneva- World Health Organization. 2008.

Available from: [Article] [Crossref]

07. Toroyan T, Peden M (eds). Youth and Road Safety. Geneva- WHO. 2007.

[Crossref]

08. Al-Khaldi YM. Attitude and practice towards road traffic regulations among students of health sciences college in aseer region. J Family Community Med. 2006;13(3)109-13. [Crossref]

09. Gharaibeh ES, Abu Abdo AM. Assessment of traffic safety and awareness among youth in AlAhsa region, Saudi Arabia. J Emerg Trends Eng Appl Sci. 2011;2;210e5.

[Crossref]

10. Lalitha D S, Naidu A, Madhavi BD. "A Study on Knowledge Attitude and Practice of Road Safety Measures among College Students in Visakhapatnam City". Journal of Evidence based Medicine and Healthcare. 2015;2(42)74397444.

DOI: $\quad 10.18410 /$ jebmh/2015/1006 [Crossref]

11. Swami HM, Puri S, Bhatia V. Road safety awareness and practices among school children of Chandigarh. Indian $\mathrm{J}$ Commun Med. 2006;31;199.

[Crossref]

12. Kulkarni $\mathrm{V}$, et al. Awareness and practice of road safety measures among undergraduate medical students in a South Indian state. Journal of Forensic and Legal Medicine. 2012.

[Article] [Crossref] 